\title{
Changes to fish assemblages visiting estuarine wetlands following the closure of commercial fishing in Botany Bay, Australia
}

\author{
Neil Saintilan, ${ }^{1 *}$ Debashish Mazumder, ${ }^{2}$ and Karen Cranney \\ ${ }^{1}$ Department of Environment and Climate Change, PO Box A290, Sydney South, NSW 1232, Australia \\ ${ }^{2}$ Australian Nuclear Science and Technology Organization (ANSTO), PMB 1, Lucas Heights, Menai, \\ NSW 2234, Australia \\ *Corresponding author: neil.saintilan@environment.nsw.gov.au
}

\begin{abstract}
A Before-After, Control-Impact sampling design was used to measure changes in fish assemblages in intertidal mangroves and saltmarsh prior to and following the closure of commercial fishing in the Botany Bay estuary, New South Wales, Australia. Of commercial species found as juveniles in the wetlands, there was a consistent pattern of decrease in numbers compared to the pre-closure surveys. Other small wetland fish (such as the Gobiidae) were also found to have decreased in numbers, with the exception of the Common Toadfish (Tetractenos hamiltoni Gray and Richardson, 1843) and the Glassfish (Ambassis jacksoniensis Macleay, 1881). Results suggest that the immediate response of an estuarine fishery to commercial fishing closure may be a predator-mediated decline in juvenile fish of both prey and predator species.
\end{abstract}

Keywords: mangrove, fyke net, saltmarsh, fishing-closure

\section{Introduction}

In an open estuary, stochastic variability in recruitment may dominate inter-annual variability in fish stocks. This model would present estuarine fish stocks as density-independent for those species with a pelagic nearshore larval phase. However, the strong relationships between habitat extent and commercial fishing catches in many estuaries in New South Wales (Saintilan, 2004) suggest a degree of density dependence. In these systems, predation and competition may be important controls on community structure (Power, 1987; Wilbur, 1988; Power, 1990).

The closure of an estuary to commercial fishing is an interesting case-study in predator-prey interactions. The immediate change to fish populations following a commercial closure would be a decrease in mortality amongst higher trophic level predators, with no immediate change in recruitment of juveniles. It could be expected that this would place increased predation pressure on prey species, which includes juveniles of commercially important species. Predation contributes significantly to high mortality rates for larval and juvenile fish (Calef, 1973; Morin, 1983; Fuiman, 1994). The contribution to recruitment made by the increased brood stock may not be felt immediately, or directly, for species with an oceanic larval stage.

Upon entering estuaries in south east Australia, juvenile fish congregate in shallow-water habitats on the fringes of estuaries (Mazumder et al., 2005). In the Botany Bay estuary, many juvenile and other small fish move into the mangrove and saltmarsh wetlands of Towra Point during spring high tides (Mazumder et al., 2005) and feed on brachyuran 
larvae and other products of the saltmarsh (Mazumder et al., 2006). A survey using buoyant pop nets demonstrated the importance of these wetlands to a number of commercially important species.

Approximately 60 commercial fishers were reported to be fishing in Botany Bay up until the commercial closure in mid-2002, using prawn trawling, net hauling, mesh netting and fish trapping. Commercial catches were dominated by (in order) Pseudocaranx dentex, Mugil cephalus, Girella tricuspidata, Acanthopagrus australis, Sillago ciliata, Melicertus plebejus, Anguilla reinhardtii, Platycephalus fuscus and Metapenaeus macleayi. The annual catch prior to closure was estimated at approximately 220 tonnes (Scribner and Kathuria, 1996). A study of the estuarine wetland fish assemblages therefore provides an insight into the response of juvenile and other prey fish stocks to increased predation pressure created by the closure of commercial fishing.

\section{Methods}

\section{Study sites}

The study compared temporal variation of nekton catch in mangrove and saltmarsh flats at Towra Point Nature Reserve, in Botany Bay with two reference sites in adjacent estuaries. The Towra Point Nature Reserve (1510 09'04" E; 340 00'36" S; Figure 1) is a relatively undisturbed sandy marine delta with mangrove forest dominated by Avicennia marina (Forsk.) Vierh. (Mazumder et al., 2005). The lower saltmarsh was dominated by a Sarcocornia quinqueflora (Bunge. ex Ung.-Sternb.) / Sporobolus virginicus (L.) Kunth, association, (Clarke and Hannon, 1967; Adam et al., 1988).

Allens Creek on the Hawkesbury River at Spencer (1510 06 $47^{\prime \prime} \mathrm{E}$; $33027^{\prime} 50^{\prime \prime} \mathrm{S}$ ) is an example of a tributary delta within the fluvial deltaic segment of the Hawkesbury River estuary. Intertidal soils consist predominantly of silts and clays, and salinities are periodically diluted by freshwater flows (Saintilan, 1997). The saltmarsh assemblage is similar to that of Towra Point, though S. australis is absent. Avicennia marina and Aegiceras corniculatum ((L.) Blanco) are abundant.

The site at Homebush Bay $\left(151009^{\prime} 50^{\prime \prime}\right.$ E; 330 $50^{\prime} 27^{\prime \prime} \mathrm{S}$ ) is also a tributary fluvial delta, occurring in the central reaches of the Parramatta River.The mangrove forest is extensive and dominated by A. marina, while the saltmarsh is patchy, and is dominated by $S$. quinqueflora, $S$. virginicus and the introduced Juncus acutus L. (Clarke and Bensen, 1988).

\section{Fish sample collection}

Fyke nets (Morton et al., 1987; Williams et al., 1996) were used in the saltmarsh and mangrove wetlands to collect fish. The 4-metre long funnelshaped fyke nets consisted of one central and two lateral wings and a $40 \mathrm{~cm}$ wide and $25 \mathrm{~cm}$ high entrance. The fyke nets were placed systematically at 50 metre intervals, facing land to sample nekton during the draining of the ebb-tide. Net location was fixed throughout the pre- and post-closure surveys.

In the pre-closure surveys, four replicate fyke nets were deployed in the saltmarsh and two replicate fyke nets were deployed in the adjacent mangrove flat. In the post-closure surveys, the number of nets deployed in the mangrove was increased to three. Fish were retrieved from the fyke nets following spring tide inundations when the tide water fully receded from the saltmarsh and mangrove. At Towra Point, fish samples were collected every month during the winter months of June, July and August, and the summer months of December, January and February, during both sampling periods (2001/2002 and 2004/2005). Fish samples from the control sites were collected during December, January and August during the same spring tidal cycles sampled at Towra Point, with the exception of December 2004 at Allen's Creek.

\section{Statistical methods}

Differences in assemblages of fish between pre and post- fishing closure were examined from the Bray-Curtis measures of dissimilarity (Bray and Curtis, 1957) using square root transformed data. Nonmetric multidimensional scaling (nMDS) plots were also used to demonstrate the patterns of fish assemblages pre and post fishing closure (Clarke and Warwick, 2001). Multivariate techniques such as ANOSIM (Clarke and Warwick, 2001) were used to test the statistical significance of differences between the fish assemblages, pre and post fishing closure. The contribution made by particular species to differences in species assemblages was determined 


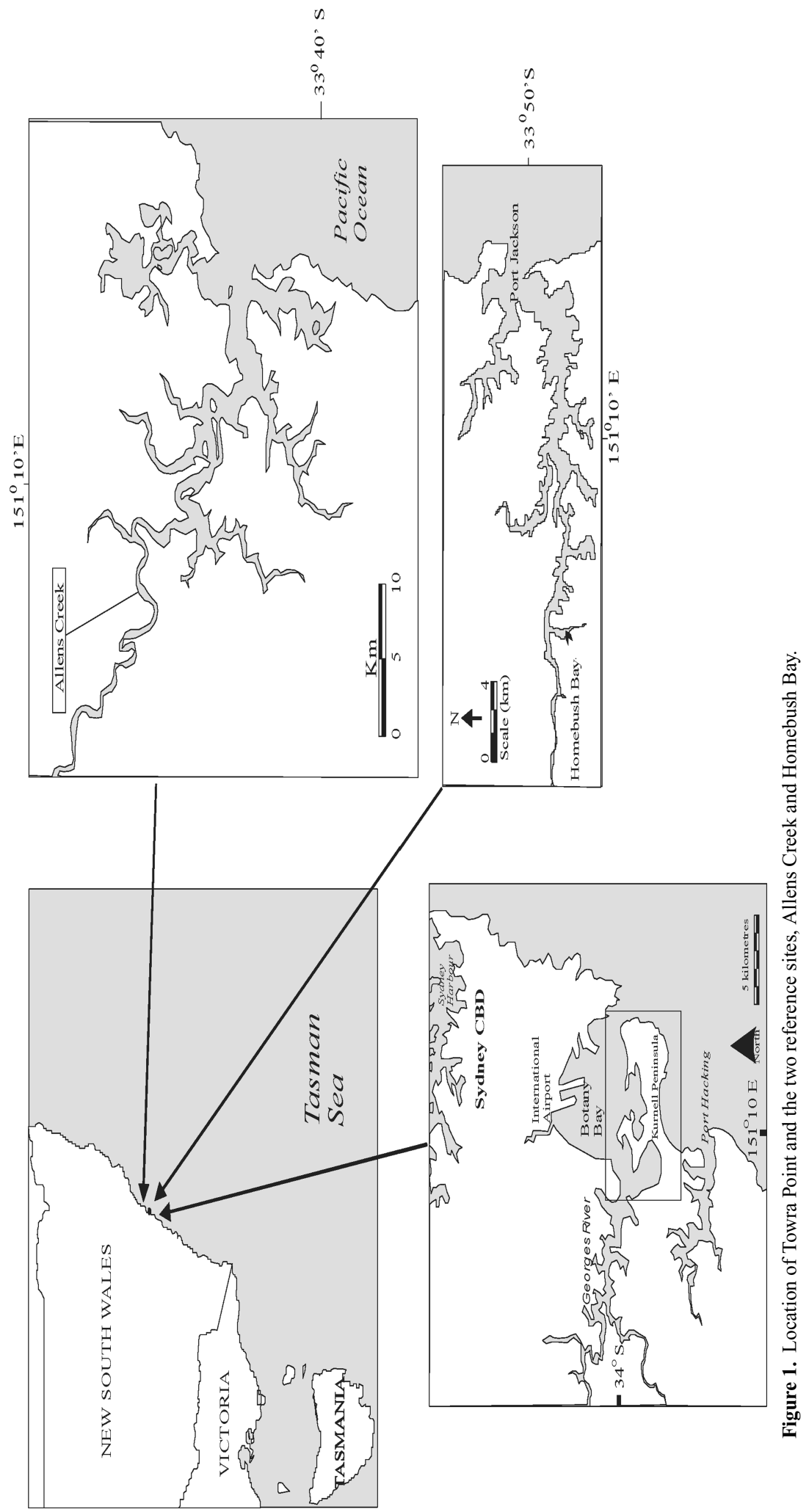


using SIMPER (similarity percentages-species contribution, Clarke and Warwick, 2001).

\section{Results}

\section{Towra point}

Table 1 shows the total fish catches within the saltmarsh and mangrove for each site, pre and post fishing closure at Botany Bay. At Towra Point, species richness within the wetlands increased from 29 species pre-closure to 33 species post-closure of commercial fishing.

Fish assemblages within the saltmarsh and mangrove forest at Towra Point showed a significant difference pre- and post-closure (ANOSIM P $=$ 0.001 and $\mathrm{P}=0.025$ respectively). The species contributing most to this difference are listed in Table 2. Within the saltmarsh, a decrease in Macrobrachium intermedium, Pseudomugil signifier andMugilogobius stigmaticus and an increase in A. jacksoniensis explained $47 \%$ of the difference. Within the mangroves, an increase in the abundance of A. jacksoniensis and a decrease in abundance of M. intermedium, Gobiopterus semivestitus and $G$. subfasciatus explained $52.5 \%$ of the difference.

Average fyke net abundances for selected individual species pre- and post-closure are shown in Figure 2. Overall, within the mangroves and saltmarsh, all species decreased in abundance postclosure, except for A. jacksoniensis and T. hamiltoni.

\section{Reference sites}

Within the saltmarsh and mangrove at Homebush Bay, species richness increased from 22 species pre-closure of commercial fishing, to 24 species post-closure (Table 1). Differences in fish assemblages between pre-closure and post-closure sampling times were detected in the saltmarsh $(\mathrm{P}=$ $0.012)$ and the mangrove $(P=0.002)$. Within the saltmarsh, an increase in $P$. signifer, $M$. paludis and Gambusia holbrooki accounted for $52 \%$ of the difference. Within the mangrove, the species most contributing to this difference was a decrease in Pseudogobius olorum, and an increase in A. jacksoniensis, G. semivestitus and P. signifer. Together, these changes accounted for over $43 \%$ of differences between pre and post-closure assemblages at Homebush Bay.

There was no difference between fish assemblages at Allen's Creek pre- and post-closure in ei- ther the saltmarsh $(\mathrm{P}=0.23)$ or the mangrove $(\mathrm{P}=$ 0.12 ). However, samples were limited to three pre and two post-closure sampling occasions.

\section{Discussion}

Juveniles of commercially important (predator) species may compete with non-commercial species at the lower-trophic level phase (Werner and Gilliam, 1984; Stein et al., 1988; Polis et al., 1989). In these circumstances, where small non-commercial species co-exist in mangrove wetlands with juvenile predators, small predators may be competitively inferior due to constraints imposed by more dramatic ontogenic shifts in diet over time (Werner and Gilliam, 1984; Persson, 1988). Juveniles may experience high mortality in these life phases, to a degree inversely related to size and ontogeny (Miller et al., 1988; Neill, 1988). One of the major causes of mortality at this stage may be predation (Werner et al., 1983; Wilbur, 1988; Fuiman, 1994).

Predation is therefore an important control on the structure of aquatic communities (Carpenter et al., 1987; Kerfoot and Sih, 1987; Wilbur, 1987; Power, 1990), and this might particularly be the case in estuarine wetlands where small fish congregate. Predators can have direct effects by imposing higher mortality rates, or indirect effects by altering the availability of alternate food sources (Kerfoot and Sih, 1987; Wootton, 1993, 1994). Behavioural effects may also be significant, with a possible increased use of shallow wetlands as predator avoidance.

One model would suggest that the effect of the closure might be to increase the numbers of juveniles of commercially important fish, particularly in the habitats where they congregate; the seagrass, mangrove and saltmarsh wetlands on the southern side of the bay. Fortuitously, we measured these populations between 2001 and 2002, and it was this assumption that prompted the repeat of the surveys in 2004-2005.

Only three species of commercial importance were observed to have increased in numbers in the 2004-2005 survey, and all were found as adults: pike eel (a single specimen of $7 \mathrm{~kg}$ ), squid, and school prawns. Of commercial species found as juveniles in the wetlands, there was a consistent pattern of decease in numbers compared to the pre-closure surveys. Other small wetland fish (such as the Gobiidae) were also found to have decreased in numbers, with the exception of T. hamiltoni and A. jacksoniensis. 


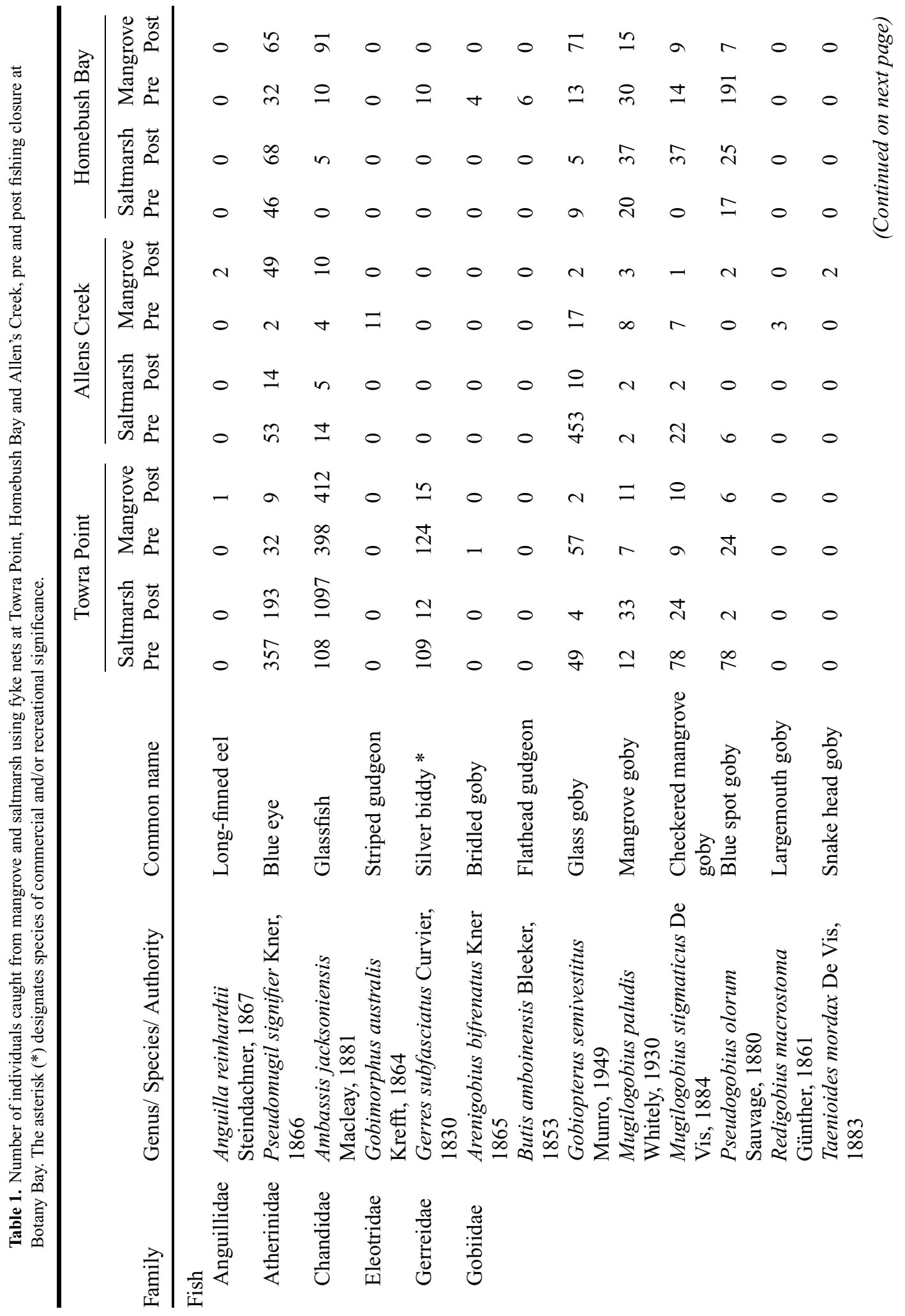




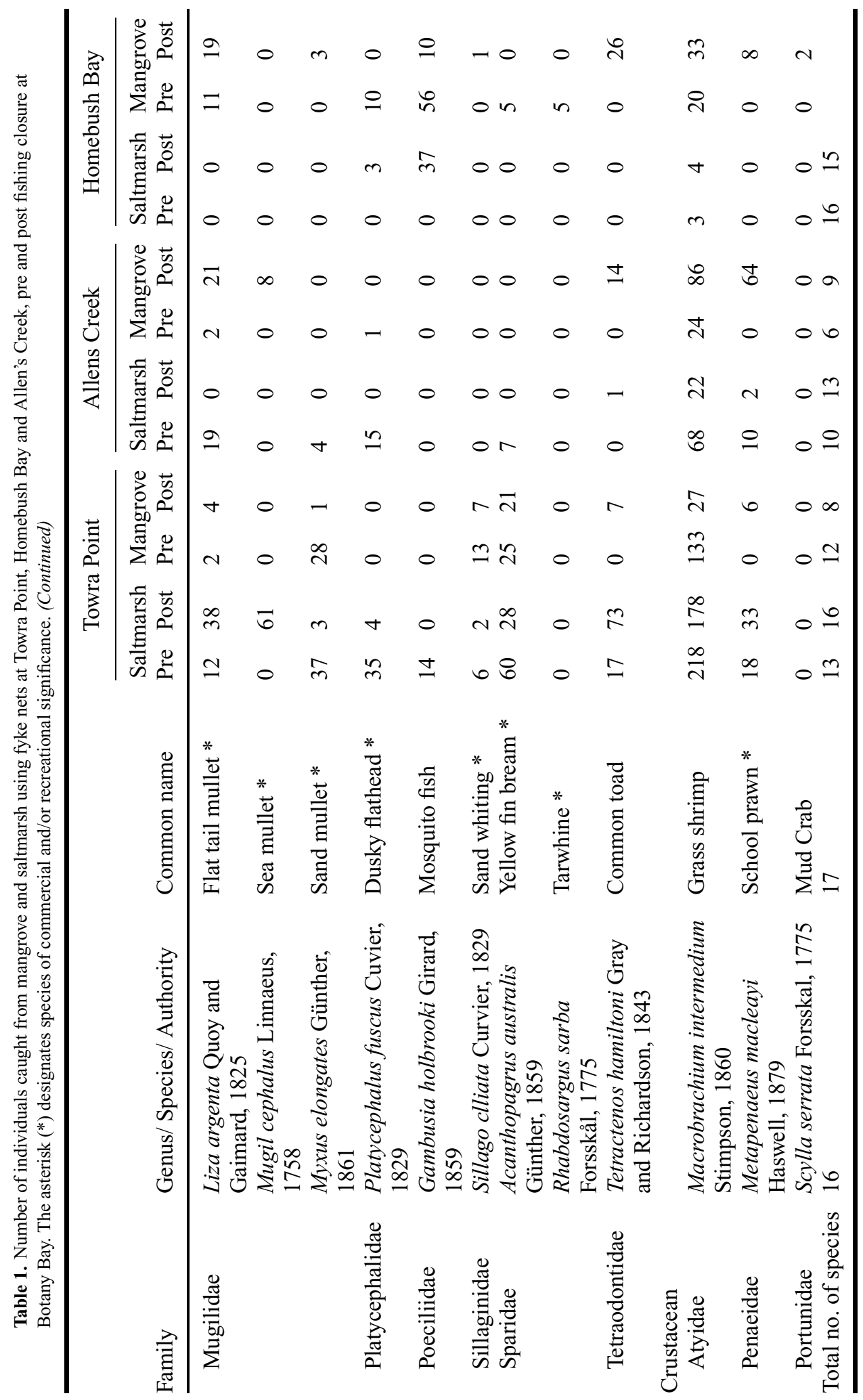


Table 2. SIMPER output showing the contribution of species to the differences in fish assemblages pre and post-closure in the Towra Point saltmarsh and mangrove. Fish are listed in order of their contribution to the differences in fish assemblages.

\begin{tabular}{lccc}
\hline Species & $\begin{array}{c}\text { Av. abundance } \\
\text { pre-closure }\end{array}$ & $\begin{array}{c}\text { Av. abundance } \\
\text { post-closure }\end{array}$ & $\begin{array}{c}\text { Cumulative \% contribution } \\
\text { to dissimilarity }\end{array}$ \\
\hline Saltmarsh & & & \\
Macrobrachium intermedium & 11.70 & 15.82 & 14.45 \\
Pseudomugil signifer & 6.73 & 17.21 & 27.36 \\
Ambassis jacksoniensis & 38.20 & 8.64 & 40.09 \\
Mugilogobius stigmaticus & 0.93 & 4.46 & 46.94 \\
Gerres subfasciatus & 0.40 & 4.64 & 53.37 \\
Gobiopterus semivestitus & 0.33 & 3.14 & 59.66 \\
Acanthopagrus australis & 1.03 & 2.89 & 65.46 \\
Platycephalus fuscus & 0.13 & 2.21 & 70.64 \\
Metapenaeus macleayi & 1.20 & 1.21 & 75.61 \\
Myxus elongatus & 2.20 & 1.79 & 80.47 \\
Tetractenos hamiltoni & 2.57 & 0.54 & 89.26 \\
Liza argenta & 1.53 & 0.61 & 93.43 \\
Mugilogobius paludis & 1.33 & 0.14 & 22.72 \\
Mangrove & & & 36.02 \\
Ambassis jacksoniensis & 31.35 & 26.87 & 44.33 \\
Macrobrachium intermedium & 1.59 & 18.27 & 52.53 \\
Gobiopterus semivestitus & 0.12 & 5.27 & 59.50 \\
Gerres subfasciatus & 0.88 & 8.87 & 66.26 \\
Mugilogobius stigmaticus & 0.88 & 2.20 & 72.61 \\
Pseudomugil signifer & 1.00 & 3.33 & 77.23 \\
Acanthopagrus australis & 1.41 & 2.00 & 80.24 \\
Mugilogobius paludis & 0.76 & 1.07 & 83.22 \\
Myxus elongatus & 0.06 & 1.80 & 91.32 \\
Tetractenos hamiltoni & 0.41 & 0.33 & \\
Pseudogobius olorum & 0.59 & 1.13 & 0.33 \\
Liza argenta & 0.29 & & \\
\hline
\end{tabular}

There are two possible interpretations of this result. One is that the change reflects inter-annual variability relating to patterns of recruitment into the bay. The vast majority of estuarine nekton have a nearshore oceanic larval stage, and it is this lifehistory stage that is key to determining year class strength. This hypothesis is supported by the results from the Homebush Bay reference site, where increases in glassfish and toadfish were also observed, along with a decrease in yellowfin bream. However, replication at this site was lower than at Towra Point. Further monitoring would be required to determine whether the marked and consistent change detected is within the range of normal variability over this timescale.

A second explanation considers the expected consequences of closing the commercial fishery. The immediate change on demographic structure of commercially harvested fish would be an increase in the adult population before any change in the juvenile cohorts. A larger adult population would place significant predation pressure on smaller fish, both commercial and non-commercially important. Connell (1998) found low rates of mortality on a species of reef fish where large predatory fish were excluded, with the magnitude of difference between caged and uncaged sites reflecting differences between locations of low and high predator density respectively.

The exception would be those fish not known to be prey of adult fish, such as Tetractenos hamiltoni, which produces a powerful neurotoxin. Such a model fits the data presented in this survey. $T$. hamiltoni were also observed to feed on A. jacksoniensis, which showed greater abundance in the post-closure survey. These two species were found also to increase at the Homebush Bay control site, 


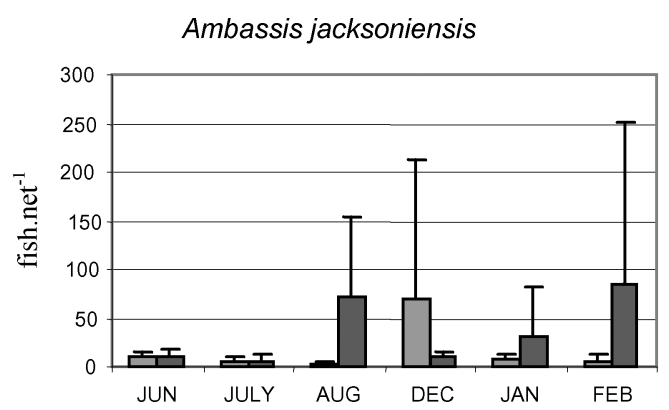

Gobiopterus semivestitus

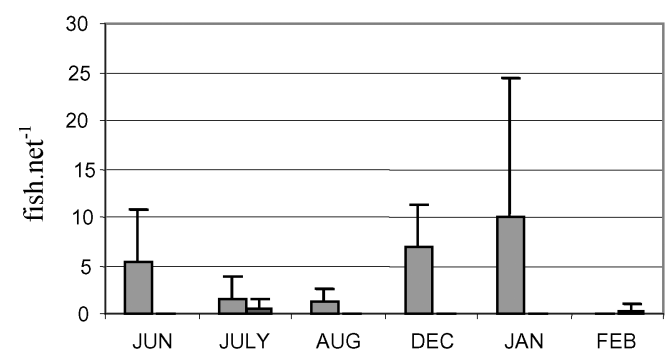

Macrobrachium intermedium

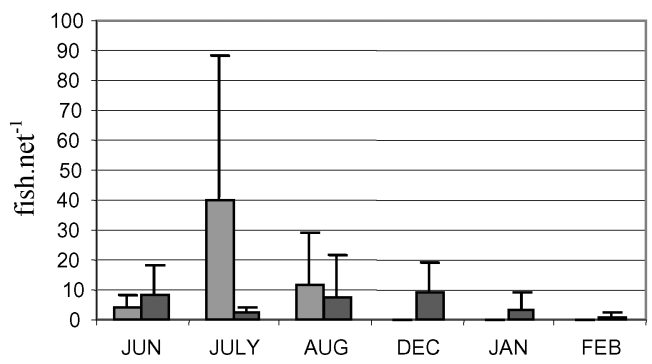

Tetractenos hamiltoni

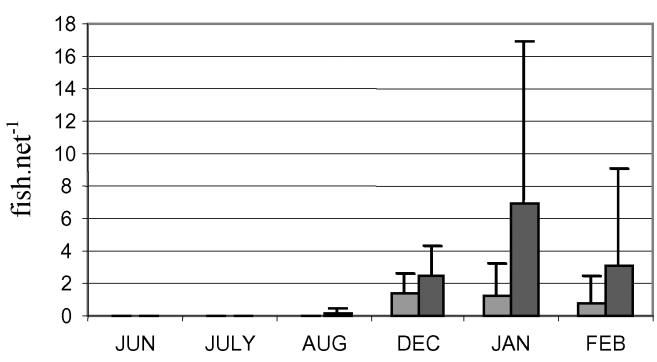

Platycephalus fuscus

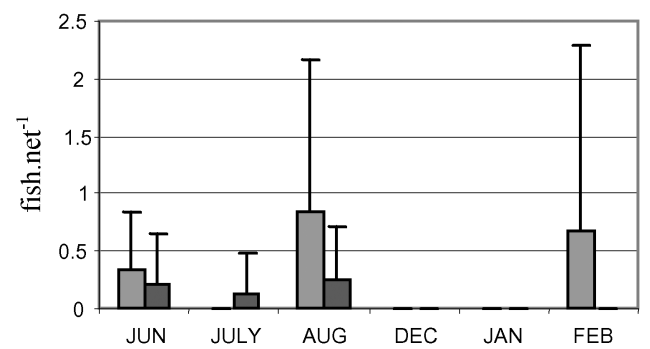

Liza argenta

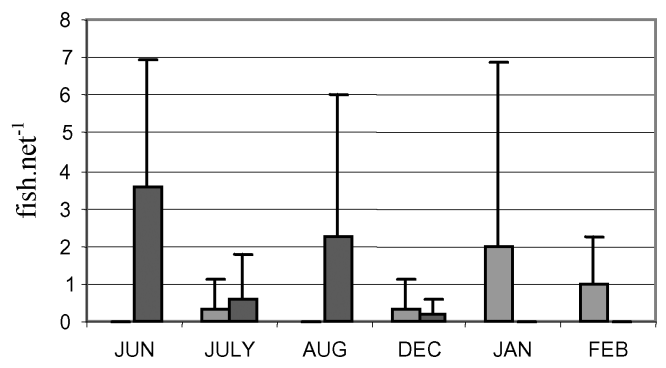

Figure 2. Pre and post-closure catches of the various fish and crustacean species at Towra Point wetlands (mean and standard deviation). Light shade $=$ Pre-closure, dark shade $=$ Post-closure.

which may suggest regionally favourable conditions for recruitment and growth over the period.

This does not mean that adult stocks would be expected to decline, because recruitment into the adult population is likely to be enhanced in the absence of commercial fishing pressure, and the proportional declines observed were not large for any species. Though there may be a lower number of juveniles, they may be more likely to become large adult fish once they cease to be effective prey, now that commercial fishing has ceased.

\section{Conclusions}

The closure of selected estuaries to commercial fishing in New South Wales over recent years has been implemented to relieve pressure on wild fish stocks and improve the prospects of recreational fishers. The assumption is that the closure of a fishery will lead to a greater abundance of commercially-targeted fish species. This research has provided a cautionary note. The relationships between fish abundance within an estuary, recruitment of juveniles from the nearshore environment, and competitive and predatory interactions between fish within an estuary are complex. Initial survey results have suggested an initial decline in the availability of juveniles of commercially important fish in the "nursery" shallow-water habitats of one estuary closed to commercial fishing, possibly due to an increase in predation by larger fish. 


\section{Acknowledgements}

The study was supported by a grant under the NSW Recreational Fishing Trust from the Department of Primary Industries. The Department of Environment and Climate Change provided access to the site. The Department of Primary Industries is thanked for the provision of nets used in this research. The authors also acknowledge the assistance of several field volunteers, especially R. Williams.

\section{References}

Adam, P., Wilson, N. C., Huntley, B., 1988. The phytosociology of coastal saltmarsh vegetation in New South Wales. Wetlands (Australia) 7, 35-84.

Bray, J. R., Curtis, J. T., 1957. An ordination of the upland forest communities of southern Wisconsin. Ecol. Monogr. 27, 325349.

Calef, G. W., 1973. Natural mortality of tadpoles in a population of Rana aurora. Ecology 54, 741-758.

Carpenter, S. R., Kitchell, J. F., Hodgson, J. R., Cochran, P. A., Elser, J. J., Elser, M. M., Lodge, D. M., Kretchner, D., He, X., von Ende, C. N., 1987. Regulation of lake primary productivity by food web structure. Ecology 68, 1863-1876.

Clarke, L. D., Hannon, N. J., 1967. The mangrove swamp and saltmarsh communities of the Sydney district. I. Vegetation, soil and climate. J. Ecol. 55, 753-771.

Clarke, K. R., Warwick, R. M., 2001. Changes in marine communities: An approach to statistical analysis and interpretation. 2nd edition. PRIMER-E; Plymouth, United Kingdom.

Clarke, P. J., Bensen, D., 1988. The natural vegetation of Homebush Bay- two hundred years of changes. Wetlands (Australia) 8, 2-15.

Fuiman, L. A., 1994. The interplay of ontogeny and scaling in the interactions of fish larvae and their predators. J. Fish Biol. $45,55-79$.

Kerfoot, W. C., Sih, A., 1987. Predation: direct and indirect impacts on aquatic communities. University Press of New England, New Hampshire.

Mazumder, D., Saintilan, N., Williams, R., 2005. Temporal variations in fish catch using pop nets in mangrove and saltmarsh flats at Towra Point, NSW, Australia. Wetlands Ecology and Management 13, 457-476.

Mazumder, D., Saintilan, N., Williams, R., 2006. Trophic relationship between itinerant fish and crab larvae in a temperate Australian saltmarsh. Mar. Freshwater Res 57, 1-7.

Miller, T. J., Crowder L. B., Rice, J. A., Marchall, E. A., 1988. Larval size and recruitment mechanisms in fishes: toward a conceptual framework. Can. J. Fish. Aquat. Sci. 45, 16571670 .

Morin, P. J., 1983. Predation, competition and the composition of larval anuran guilds. Ecol. Monogr. 53, 119-138.
Morton R. M., Pollock B. R. Beumer, J. P., 1987. The occurrence and diet of fishes in a tidal inlet to a saltmarsh in southern Moreton Bay, Queensland. Australian Journal of Ecology 12, 2127-237.

Neill, W. E., 1988. Community responses to experimental nutrient perturbations in oligotrophic lakes. In: B. Ebenman, L. Persson (Eds.), Size structured populations: ecology and evolution, pp. 203-218. Springer-Verlag, Berlin.

Persson, L., 1988. Asymmetries in competitive and predatory interactions in fish populations. In: B. Ebenman L. Persson (Eds.), Size structured populations: ecology and evolution, pp. 203-218. Springer-Verlag, Berlin.

Polis, G. A., Myers, C. A., Holt, R. D., 1989. The ecology and evolution of intraguild predation: potential competitors that eat each other. Annu. Rev. Ecol. Syst. 20, 297-330.

Power, M. E., 1987. Predator avoidance by grazing fishes in temperate and tropical streams: importance of stream depth and prey size. In: W. C. Kerfoot, A. Sih (Eds.), Predation: direct and indirect impacts on aquatic communities, pp. 333-351. University Press of New England, New Hampshire.

Power, M. E., 1990. Effects of fish in river food webs. Science 250, 811-814.

Saintilan, N., 1997. Mangroves as successional stages on the Hawkesbury River Estuary, New South Wales. Wetlands (Australia) 16 (2), 99-107.

Saintilan, N., 2004. Relationships between estuarine geomorphology, wetland extent and fish landings in New South Wales estuaries. Estuar. Coast. Shelf S. 61, 591 -601.

Scribner, E. A., Kathuria, A., 1996. New South Wales Commercial Fisheries Statistics. NSW Department of Primary Industries.

Stein, R. A., Threlkeld S. T., Sandgren, C. D., Sprules, W. G., Persson, L., Werner, E. E., Neill, W. E., Dodson, S. I., 1988. Size-structured interactions in lake communities. In: S. R. Carpenter (Ed.), Complex interactions in lake communities, pp. 161-180. Springer-Verlag, NY.

Werner E. E., Gilliam, J. F., 1984. The ontogenetic niche and species interactions in size-structured populations. Annual Review of Ecology and Systematics 15, 393-425.

Werner, E. E., Gilliam, J. F., Hall D. J., Mittelbach, G. G., 1983. An experimental test of the effects of predation risk on habitat use in fish. Ecology 64, 1540-1548.

Wilbur, H. M., 1987. Regulation of structure in complex systems: experimental temporary pond communities. Ecology $68,1437-1452$.

Wilbur, H. M., 1988. Interactions between growing predators and growing prey. In: B. Ebenman, L. Persson (Eds.), Sizestructured populations: ecology and evolution, pp. 157-172. Springer-Verlag, Berlin.

Wootton, J. T., 1993. Indirect effects and habitat use in an intertidal community: interaction chains and interactions modifications. Am. Nat. 141, 71-89.

Wootton, J. T., 1994. The nature and consequences of indirect effects in ecological communities. Annu. Rev. Ecol. Syst. 25, 443-466. 